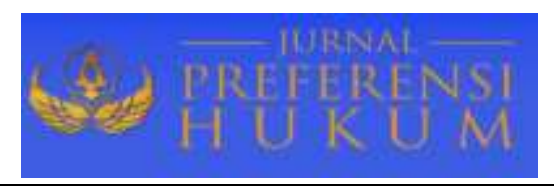

Jurnal Preferensi Hukum | ISSN: XXXX | E-ISSN: XXXX

Vol. 1, No. 2 - September 2020, Hal. 128-132| Available Online

at https://www.ejournal.warmadewa.ac.id/index.php/juprehum

DOI: http://doi.org/10.22225/jph.v1i2.2349.128-132

\title{
PEMECAHAN SERTIFIKAT HAK ATAS TANAH YANG SEDANG DIBEBANI HAK TANGGUNGAN
}

\author{
I Putu Gian Favian Adhi Pradana, I Made Suwitra, I Ketut Sukadana \\ Fakultas Hukum Universita Warmadewa, Denpasar-Bali, Indonesia
}

\begin{abstract}
Abstrak
Tujuan adanya prosedur dari pemecahan sertifikat masih terikat hak tanggungan yaitu untuk memberikan perlindungan hukum bagi pihak kreditur, jika terdapat pemecahan sertifikat maka seluruh pemecahanya akan dibebani ulang sesuai dengan kredit yang dipinjam. Penelitian ini bertujuan untuk mengetahui perlindungan hukum bagi pihak bank terhadap pemecahan sertifikat hak atas tanah yang sedang dibebani hak tanggungan dan untuk mengetahui akibat hukum pemecahan sertifikat hak atas tanah yang sedang dibebani hak tanggungan. Penelitian ini menggunakan jenis penelitian hukum normatif, dengan pendekatan perundang-undangan (The Statute Approach) dan pendekatan konseptual. Hasil penelitian menunjukkan bahwa upaya perlindungan hukum bagi pihak bank terhadap pemecahan sertifikat hak atas tanah yang sedang dibebani hak tanggungan, dapat dilakukan dengan pembuatan surat kuasa membebankan dan pembuatan untuk menjual. Dalam praktiknya, untuk mendapatkan suatu perlindungan hukum terhadap kepastian jaminan yang akan dipecahkan, Pihak Bank akan meminta dibuatnya suatu surat kuasa untuk melakukan penjualan. Dalam hal ini dibuatnya surat kuasa menjual oleh debitur pihak bank dan juga dapat menjual jaminan tersebut. Akibat hukum pemecahan sertifikat yang sedang dibebani hak tanggungan menjadi hapus Hak Tanggungan dan akan dibebani ulang pada pemecahan tersebut.
\end{abstract}

Kata Kunci : Pemecahan Sertifikat; Pembebanan Hak Tangungan; Perlindungan Hukum

\begin{abstract}
The purpose of the procedure for certificate management is still bound by mortgage rights, namely to provide legal protection for creditors, if there is a certificate holder, all of the breakers will be re-burdened according to the loan borrowed. This study aims to look at the legal protection for the bank against land title certificate holders who are encumbered with mortgage rights and legal responsibilities for land title certificates that are encumbered with mortgage rights. This research uses a type of normative legal research, with an invited-invited approach (The Statute Approach) and a conceptual approach. The results showed that the legal protection measures for the bank against the management of land title certificates that were encumbered with mortgage rights could be done by making a power of attorney to charge and making them to sell. In practice, in order to obtain a legal protection against the certainty of the guarantee to be resolved, the Bank will ask permission to make a power of attorney to make the sale. In this case a power of attorney is made to sell by the bank's debtor and can also sell the guarantee. As a result of the legal law, the certificate which is being burdened with a mortgage will be nullified and will be re-burdened on the owner.
\end{abstract}

Keywords: Certificate Breaking; Imposition of Cover Rights; Legal Protection

\section{PENDAHULUAN}

Dalam rangka mencapai tujuan pembangunan nasional Indonesia harus dilaksanakan pembangunan di segala aspek salah satunya pembangunan di bidang ekonomi. Pembangunan ekonomi merupakan hal penting dimana bertujuan mewujudkan kesejahteraan rakyat (Sutedi, 2010). Dengan meningkatnya pembangunan di bidang ekonomi, maka meningkat pula keperluan akan dana yang sebagian besar diperoleh dari perkreditan. Maka dari itu pihak bank di dalam memberikan perkreditan akan meminta suatu jaminan dari debitur untuk memberikan kepastian hukum kepada pihak bank (Bahsan, 2007).

Kredit memperlancar usaha dan sangat berperan penting bagi perekonomian di Indonesia baik perusahan produksi dalam hal di kembangkan mandiri (Supriyanto, 2006). Sarana mempunyai peran kuat dalam pengadaan dana yaitu pihak bank dengan cara memberikan pinjaman melalui 
kredit. Dalam hal ini fungsi bank untuk mengumpulkan dan menyalurkan dana bersumber dari masyarakat mempunyai tujuan pembangunan nasional dan meningkatkan taraf masyarakat menjadi sejahtera. Pihak bank disini memberikan pinjaman dalam bentuk kredit dan tentunya bukan tanpa risiko, risiko disini yang dimaksud debitor tidak membayar hutang padahal dalam undang-undang perjanjian tersebut dibayar bertahap (Yetti, 2012).

Risiko umumnya dapat terjadi dalam perkreditan tersebut adalah kemacetan perkreditan, pergerakan pasar dan terdapat kelemahan dalam aspek yuridis yaitu tuntutan hukum ketiadaan undang-undang untuk mengatur hal tersebut (Harun, 2010). Perlu diperhatikan risiko-risiko tersebut dalam hal ini dapat merugikan pihak kreditor atau bank, untuk itu perlu keyakinan pihak bank untuk mengkalkulasi kemampuan debitor dalam hal membayar hutang tersebut maka perlu dilakukan penilaian secara seksama proses perkreditan tersebut dimungkinkan terjadi tindakan wanprestasi dilakukan pihak debitor untuk itu diperlukan suatu kepastian hukum dalam hal ini dilakukan pembebanan hak tanggungan (Sukmawati, 2019). Jaminan hak tanggungan dapat berupa benda bergerak dan tidak bergerak yang digunakan untuk melunasi utang debitor melalui pelelangan sesuai dengan peraturan berlaku dan sebagian akan dikembalikan kepada debitor (Gatot Supramono, 1996)

Masyarakat berperan pada pembangunan nasional di segala aspek atau bidang khususnya pada bidang properti dapat memberikan pendapat negara. Dalam hal tersebut sangat berhubungan dengan hak-hak atas tanah yang dijadikan jaminan untuk kepentingan bank, tanah diberi pembebanan hak tanggungan untuk kepentingan pengembang tanah yang diatasnya terdapat bangunan perlu dipecah sesuai luas tanah. Hak atas tanah tersebut dipecah untuk kepentingan pengembang dalam penjualan dan pemberian bangunan. Sertifikat tersebut dipecah menjadi beberapa bagian luas tanah. Asas pemisahan horizontal disebutkan tanah dan bangunan bukan satu kesatuan tidak terpisahkan. Pada praktiknya memungkinkan perbuatan hukum tanah meliputi bangunan diatasnya, setiap tanah diatasnya terdapat bangunan dan ikut dijadikan objek jaminan hal tersebut menyulitkan bagi pengembang untuk menjual unit rumah. Oleh sebab itu pada bidang properti yang memiliki lahan atas tanah yang luas untuk dijadikan perumahan harus melakukan pemecahan sertifikat induknya.

Apabila sertifikat tersebut masih terikat hak tanggungan atau beban lainnya hal tersebut baru boleh dipecah apabila sudah mendapatkan izin atau persetujuan tertulis mengenai penghapusan beban tersebut (Sinaga et al., 2019). Dalam hal ini pemisahan bidang tanah perlu memperhatikan prosedur dan peraturan yang berlaku agar tidak merugikan kepentingan pihak kreditor atau bank (Fauzi, 2010). Hasil pemisahan tersebut akan tetap dibebani ulang dari pihak bank. Pada praktiknya kendala terhadap pemecahan tersebut apabila setelah dipecah harus dibebani hak tanggungan kembali sebegaimana berdasarkan pada pasal 113 angka 4 Peraturan Menteri Negara Agraria/Kepala Badan Pertanahan Nasional Nomor 3 Tahun 1997 yaitu Tentang Ketentuan Pelaksanaan Peraturan Pemerintah Nomor 24 Tahun 1997 tentang pendaftaran tanah.

Berdasarkan uraian latar belakang diatas, maka penelitian ini bertujuan untuk mengetahui perlindungan hukum bagi pihak bank terhadap pemecahan sertifikat hak atas tanah yang terikat hak tanggungan, serta untuk mengetahui dampak hukum dari pemecahan sertifikat hak atas tanah terikat hak tanggungan.

\section{METODE PENELITIAN}

Dalam penelitian ini penulis menggunakan metode penelitian hukum normatif karena adanya kekaburan norma terkait kasus pemecahan sertifikat yang sedang di bebani hak tanggungan yang dilakukan oleh debitur tanpa ijin dari pihak kreditur atau bank yang mana akan menimbulkan kerugian pada sebagian pihak terutama pada pihak kreditur, dengan pendekatan perundang- undangan (The Statute Approach) dan pendekatan konseptual. Adapun sumber bahan hukum yang digunakan penulis yakni bersumber dari penelitian dan kepustakaan, berupa:

1. Undang-undang Nomor 5 Tahun 1960 tentang Peraturan Dasar Pokok- pokok Tambahan Lembaran Negara Republik Indonesia Nomor 2043, Undang-Undang Nomor 10 Tahun 1998 tentang Perbankan Tambahan Lembaran Negara Republik Indonesia Nomor 3790, UndangUndang Republik indonesia Nomor 4 Tahun 1996 Tentang Hak Tanggungan Atas Tanah Beserta Benda-Benda Yang Berkaitan Dengan Tanah Tambahan Lembaran Negara Republik Indonesia Nomor 3632, Peraturan Pemerintah Nomor 24 Tahun 1997 Tentang Pendaftaran Tanah Tambahan Lembaran Negara Republik Indonesia Nomor 3696, Peraturan Menteri/Kepala BPN 
Nomor 3 Tahun 1997 Tentang Ketentuan Pelaksanaan Peraturan Pemerintah Nomor 24 Tahun 1997 Tentang Pendaftaran Tanah.

2. Bahan hukum sekunder yaitu bahan-bahan hukum yang diperoleh dari buku literatur dan hasil karya ilmiah sarjana.

Teknik pengumpulan bahan hukum yang digunakan dalam penelitian ini adalah Dokumentasi yaitu kegiatan yang dimana mengumpulkan dari berbagai suatu bahan atau dokumen untuk mendapatkan suatu keterangan dan akan disebarkan kepada pengguna. Dan pencatatanya dalam bentuk tulisan dan ditulis pada kertas, selanjutnya akan diakhiri dengan pembuatan laporan. Setelah bahan hukum primer dan bahan hukum sekunder terkumpul maka bahan hukum tersebut diolah dan dianalisis dengan menggunakan metode interpretasi, yaitu metode dimana kita menafsirkan terhadap suatu masalah atau objek dari sebuah pemikiran, selanjutnya disajikan dalam bentuk jurnal.

\section{HASIL PENELITIAN DAN PEMBAHASAN}

\section{Perlindungan Hukum bagi Pihak Bank terhadap Pemecahan Sertifikat Hak atas Tanah yang sedang Dibebani Hak Tanggungan}

Hak tanggungan digunakan karena ada pihak -pihak (subjek) dan suatu jaminan (objek). Keduanya merupakan unsur yang harus ada di dalam Hak Tanggungan, subjek tanpa objek maka Hak Tanggungan tidak akan bisa berjalan, begitu juga sebaliknya. Subyek Hak tanggungan adalah orang yang terlibat dalam hak tanggungan Dalam Pasal 8 UU No. 4 Tahun 1996 tentang hak tanggungan atas tanah beserta benda-benda yang berkaitan dengan tanah menyebutkan bahwa pihak yang memberikan pembebanan hak tanggungan mempunyai kewenangan di dalam melakukan tindakan hukum. Dalam melakukan perbuatan hukum pada objek hak tanggungan harus diberikan oleh pemberi tanggungan karena lahirnya hak tanggungan pada saat sudah didaftarkan harus dibuktikan keaslian. Pada praktiknya, upaya perlindungan hukum yang dapat dilakukan kreditor selaku pemegang hak tanggungan di dalam pemecahan sertifikat yang dibebani hak tanggungan yaitu:

1. Pembuatan Surat Kuasa Membebankan Hak Tanggungan Sebelum Dilaksanakannya Pemecahan Sertifikat. Dalam hal memberikan perlindungan hukum terhadap pinjaman yang diberikan kepada debitor dilakukan dengan pembuatan surat kuasa pembebanan hak tanggungan sebelum dilakukan pemecahan sertifikat untuk itu sebagai pemegang hak tanggungan diharapkan hadir dihadapan Pejabat Pembuat Akta Tanah (PPAT) untuk melakukan pembebanan (Usman, 2008). Pasal 15 Undang-undang hak tanggugan untuk pembuatan surat kuasa pembebanan disebutkan:

a. Surat kuasa hanya boleh dibuat oleh notaris dalam bentuk akta sebagai berikut:

1. Tidak dibolehkan membuat kewenangan lain selain pembebanan hak tanggungan seperti menjual, sewa atau memperpanjang hak atas tanah tersebut.

2. Tidak dibolehkan tercantum kuasa subtitusi yaitu pergantian orang sebagai penerima kuasa.

3. Dicantumkan keterangan jelas mengenai objek hak tanggungan seperti identitas kreditor dan debitor

2. Pembuatan Surat Kuasa Untuk Menjual. Pihak Bank dalam praktiknya untuk mendapatkan suatu perlindungan hukum terhadap kepastian jaminan yang akan dipecahkan akan meminta dibuatnya suatu surat kuasa yaitu untuk melakukan penjualan. Dalam hal ini atas dibuatnya surat kuasa menjual oleh debitur pihak bank dapat menjual jaminan tersebut. Surat Kuasa Jual ini, sesuai keinginan Bank akan dipergunakan dalam melakukan peralihan hak atas tanah apabila terjadi itikad buruk atau wanprestasi dari pihak peminjam. (Hasil Wawancara Dengan Gede Seputra, Tanggal 26 Maret 2019). Sehingga apabila debitor ingkar janji untuk mengikatkan kembali hak tanggungannya kepada Bank maka kreditor (Bank) akan menjual tanah milik debitor tersebut berdasarkan kuasa jual untuk mengambil pelunasan piutangnya. Pasal 1792 KUH Perdata disebutkan: Pemberian kewenangan adalah orang yang memberi kewenangan kepada yang menerima kewenangan tersebut. Pemberian batasan dalam hal pemberi kuasa memberikan persetujuan kepada orang lain untuk menyelenggarakan suatu urusan tertentu.

Persetujuan berdasarkan pasal 1313 KUH Perdata yaitu suatu tindakan hukum dimana satu orang atau lebih mengikat dirinya dan pasal 1338 ayat (1) KUH Perdata memberikan kebebasan untuk menetukan isi persetujuan setelah itu diberi kuasa memiliki kuasa untuk bertindak sesuai 
keinginan pemberi kuasa dan akan menjadi tanggung jawab si pemberi kewenangan. Pemberian kewenangan umumnya adalah perjanjian sepihak bahwa kewajiban dilaksanakan prestasi tersebut pada penerima kuasa. Arti kuasa mengandung pemberian wewenang bahwa penerima kuasa dapat melakukan tindakan hukum dan sah sebagai perbuatan yang dilakukan pemberi kewenangan tersebut.

\section{Akibat Hukum Pemecahan Sertifikat yang sedang Dibebani Hak Tanggungan}

Ada beberapa akibat hukum pemecahan sertifikat yang sedang dibebani hak tanggungan, yakni:

1) Hapusnya hak tanggungan. Berdasarkan ketentuan Pasal 18 Undang-undang Hak Tanggungan ditentukan bahwa; hak Tanggungan hapus karena beberapa hal yakni: lunasnya hutang yang dari pada pembebanan tersebut. Selanjutnya, dihapusnya pembebanan tersebut. Yang terakhir, dibersihkanya pembebanan tersebut dari pengadilan negeri.

2) Pencoretan Hak Tanggungan. Setelah hapusnya hak tanggungan, selanjutnya perlu dilakukan pencoretan hak tanggungan untuk mendapatkan kepastian hukum bahwa sertifikat tersebut tidak terikat hak tanggungan.

3) Akibat Hukum Pemecahan Sertifikat, yakni Pemecahan Bidang Tanah. Berdasarkan peraturan Pasal 48 ayat (1) PP No. 24/1997, bahwa pemecahan bidang tanah adalah proses pemecahan menjadi beberapa bagian bidang tanah sesuai permintaan yang bersangkutan.

\section{SIMPULAN DAN SARAN}

1. Simpulan

Adapun simpulan dari penulis dilihat dari pembahasan tersebut diatas, yakni: pemecahan sertifikat masih dibebani hak tanggungan dapat dilakukan dengan pembuatan surat untuk pembebanan dan dibuatan surat kuasa menjual yaitu Pihak Bank dalam praktiknya untuk mendapatkan suatu perlindungan hukum terhadap kepastian jaminan yang akan dipecahkan meminta dibuatnya suatu surat untuk menjual yaitu untuk melakukan penjualan oleh peminjam kredit setelah pihak bank dapat menjual jaminan tersebut. Kemudian, hapusnya Hak Tanggungan harus sesuai berdasarkan ketentuan pasal 18 Undang-undang Hak Tanggungan setelah hapusnya hak tanggungan dan terbagi menjadi beberapa bagian sertifikat maka akan dibebani hak tanggungan ulang untuk seluruhnya maupun sebagian sertifikat sesuai dengan kredit yang dipinjam oleh debitur.

\section{Saran}

Berdasarkan pembahasan di atas, hendak disampaikan beberapa saran ke berbagai pihak, yakni: Pihak bank selaku kreditor pemegang Hak Tanggungan di dalam perlindungannya, sebelum pelaksanaan permohonan pemecahan sertifikat perlu mengantisipasi hambatan yang mungkin timbul pasca pemecahan sertifikat tersebut, misalnya dengan membuat suatu surat pernyataan dari debitor, perjanjian atau kuasa khusus yang melindungi kepentingan pihak bank. Kemudian, pencoretan roya dilakukan untuk mendapatkan kepastian hukum bahwa sertifikat yang bersangkutan tidak terikat hak tanggungan sekalipun tanpa dilampirkannya sertifikat hak milik dan sertifikat hak tanggungan, percoretan roya dapat dilaksanakan karena hal tersebut akan dicatat saja pada buku tanah hal tersebut sesuai dengan peratura pasal 2 ayat (3) undang-undang hak tanggungan.

\section{DAFTAR PUSTAKA}

Bahsan, M. (2007). Hukum Jaminan dan Jaminan Kredit Perbankan di Indonesia. PT. Raja Grafindo Persada.

Fauzi, A. (2010). Eksistensi Hak Tanggungan dalam Kredit Perbankan. INOVATIF Jurnal Imu Hukum, 2(3), 87-101.

Gatot Supramono. (1996). Perbankan dan Masalah Kredit Suatu Tinjauan Yuridis. Djambatan.

Harun, B. (2010). Penyelesaian Sengketa Kredit Bermasalah. PustakaYustisia.

Sinaga, T., Kistiyah, S., \& Nurasa, A. (2019). Status Hukum Pemecahan Sertipikat Hak atas Tanah yang sedang Terikat Hak Tanggungan. Jurnal Tunas Agraria, 2(1).

Sukmawati, M. N. (2019). Personal Guarante Terhadap Perjanjian Kredit Dengan Jaminan Hak Tanggungan. Airlangga Development Journal, 3(1), 54.

Supriyanto. (2006). Pemberdayaan Usaha Mikro, Kecil dan Menengah (UMKM) Sebagai Salah Satu Upaya Penanggulangan Kemiskinan. Jurnal Ekonomi Dan Pendidikan, 3(1), 1-16. 
Sutedi, A. (2010). Hukum Hak Tanggungan. Sinar Grafika.

Usman, R. (2008). Hak Jaminan Keperdataan. Sinar Grafika.

Yetti, F. D. (2012). Bank : Studi Komparatif Antara Ekonomi Konvensional Dan Ekonomi Islam. AlFikra : Jurnal Ilmiah Keislaman, 11(1), 133-164. 